\title{
PEMETAAN POTENSI UNGGUL ANAK USIA DINI TK TUNAS KEJAKSAAN
}

\author{
Rosalina Dewi Heryani' ${ }^{1)}$, Adeng Hudaya ${ }^{2)}$, Irna Kumala ${ }^{3)}$ \\ Program Studi Pendidikan Ekonomi, FIPPS, Universitas Indraprasta PGRI \\ rosalina.dewi7@gmail.com, adeng.hudaya87@gmailcom,irnakumala@yahoo.com
}

\begin{abstract}
Abstrak
Tujuan dari penelitian ini adalah untuk mengetahui bagaimana cara memetakan potensi unggul anak usia dini serta aplikasinya dalam kehidupan sehari-hari. Metode penelitian menggunakan pendekatan kualitatif, data di peroleh dengan cara observasi, wawancara dan studi literatur. Berdasarkan hasil dan pembahasan di simpulkan bahwa pemetaan potensi unggul dapat dilakukan melalui 5 langkah antara lain menyusun program stimulasi, membuat daftar minat dan bakat, uji coba minat dan bakat, penajaman profesi dan make a life plan. Ditemukan fakta bahwa hampir $90 \%$ orangtua TK Tunas Kejaksaan belum menemukan bakat, minat dan potensi unggul anaknya.
\end{abstract}

Kata Kunci : potensi unggul, anak usia dini

\begin{abstract}
The purpose of this research is to know how to map the superior potential of the children at the early age and to apply it to their daily life. The method of the research is using qualitative approach, and the data are obtained with observations, interviews and also literature studies. In term of result and studies, we found that map and superior potential can be done throught 5 levels, those are arranging stimulation program, making the list of childrens interests and aptitudes, do the trials for these fot this interests and aptitudes, sharpening the profession and finally make a life plan. And the conclution is, we found the fact that almost $90 \%$ parents of Tunas Kejaksaan kindergarden havent fond their children's interest, aptitudes, and their superior potential.
\end{abstract}

Keywords : superior potential, children at the early age

\section{PENDAHULUAN}

\section{Latar Belakang}

Setiap anak terlahir cerdas dan unik, mereka lahir dengan membawa bibit unggul masing-masing. Keunikan setiap anak harus disadari sepenuhnya oleh orangtua, sehingga orangtua tidak membanding-bandingkan anaknya dengan anak lain. Potensi unggul anak sangat berhubungan erat dengan minat dan bakat. Dalam Kamus Besar Bahasa Indonesia, minat adalah kecenderungan hati yang tinggi terhadap sesuatu, gairah keinginan. Dalam bahasa Inggris, kita mengenal istilah "Passion". Passion adalah minat kuat disertai keinginan yang juga kuat. Minat dapat lahir dari dalam atau dari luar diri seorang anak. Sedangkan bakat adalah potensi bawaan lahir. Karena bawaan lahir, maka tidak ada bakat yang merupakan hasil bentukan. Bakat sudah ada sejak anak lahir. Setelah ia ditempa barulah ia bersinar. Bakat anak adalah titipan yang diberikan Tuhan kepada anak. Orangtua bukanlah penentu masa depan anak. Tetapi orangtua berperan untuk membantu agar potensi-potensi yang dititipkan Tuhan kepada anak bisa keluar, ditemukan, dan tumbuh berkembang. Membantu me- 
nemukan dan menumbuhkan bakat, berarti orangtua harus fokus pada kekuatan, bukan pada kelemahan anak.

Dewasa ini potensi unggul seorang anak sangat beragam. Prof. Howard Gardner, seorang ahli psikologi kognitif dari Universitas Harvard, meneliti tentang kecerdasan manusia. Ia menemukan bahwa setiap orang memiliki beberapa kecerdasan, tidak hanya satu kecerdasan. Seseorang dapat dikatakan cerdas bila ia dapat memecahkan masalah yang dihadapi dalam hidupnya dan mampu menghasilkan sesuatu yang berharga atau berguna bagi umat manusia (Lestari dkk, 2015:81). Menurut Prof. Howard Gardner terdapat 8 kecerdasan ganda, antara lain : Kecerdasan logika/matematika, kecerdasan verbal/bahasa, kecerdasan interpersonal, kecerdasan intrapersonal, kecerdasan fisik/kinestetik, kecerdasan musikal, kecerdasan visual/spasial dan kecerdasan naturalis.

Untuk mengenali potensi unggul anak, peran utama orangtua adalah memberikan lingkungan yang nyaman untuk tumbuh dan berkembang. Selain itu tugas orangtua mendampingi, menyemangati, menjadi teman diskusi, menguatkan agar anak terus semangat menempa diri, dan yang tidak kalah pentingnya adalah menjaga agar aktivitas-aktivitas pengembangan potensi berada dalam koridor yang sehat. Dimana ukurannya adalah anak menikmati proses yang dijalaninya dan bukan melakukan kegiatannya dengan terpaksa.

Namun kenyataannya masih banyak ditemukan guru dan orangtua yang belum mengetahui dan paham mengenai potensi unggul yang dimiliki peserta didik dan anaknya. Padahal dengan mengetahui potensi unggul anak maka guru dan orangtua akan mudah dalam membimbing dan mengarahkan anak. Sehingga biaya yang akan dikeluarkan untuk bersekolah akan menjadi investasi bukan expenses.

\section{Tujuan Kegiatan}

Oleh sebab itu tujuan dari kegiatan ini adalah untuk menjelaskan bagaimana cara memetakan potensi unggul anak usia dini serta aplikasinya dalam kehidupan sehari-hari.

\section{Tinjauan Pustaka}

1. Potensi Unggul

a. Pengertian Potensi Unggul

Dalam Kamus Besar Bahasa Indonesia, Minat adalah "kecenderungan hati yang tinggi terhadap sesuatu". Menurut Surya (2003:100) minat adalah "rasa senang atau tidak senang dalam menghadapi suatu objek". Hal senada juga dikemukakan oleh Slameto (2003:180), yang menyatakan bahwa minat sebagai suatu rasa lebih suka dan rasa keterikatan pada suatu hal atau aktivitas, tanpa ada yang menyuruh. Minat pada dasarnya adalah penerimaan akan suatu hubungan antara diri sendiri dengan sesuatu di luar diri.

Menurut Edy (2014:5) bakat adalah potensi bawaan. Karena bawaan lahir, tidak ada bakat yang merupakan hasil bentukan. Bakat sudah ada sejak anak lahir dan bakat sangat erat kaitannya dengan hasil. Sedangkan potensi unggul adalah potensi yang terbaik diantara semua potensi yang dimiliki anak.

b. Pentingnya Memahami Potensi Unggul

Minat memainkan peranan yang penting dalam kehidupan seseorang dan mempunyai dampak yang besar atas perilaku dan sikap. Sepanjang masa anak- 
anak, minat menjadi sumber motivasi yang kuat untuk belajar. Anak yang berminat terhadap sebuah kegiatan, baik permainan ataupun pekerjaan akan berusaha lebih keras lagi untuk belajar dibandingkan dengan anak yang kurang berminat atau merasa bosan. Minat akan mempengaruhi kualitas pencapaian hasil belajar (Syah, 1999;136).

Bakat juga mempunyai peranan yang penting bagi seorang anak. Sehingga bagi guru dan orangtua, harus memahami sifat-sifat bakat dengan nilai-nilai dan fungsinya, agar dalam memberikan bimbingan dapat sesuai dan tepat. Ellen Winner, seorang ahli di bidang kreativitas dan anak berbakat, mendeskripsikan tiga kriteria yang menjadi ciri anak berbakat yaitu (Santrock, 2008:252) : 1) Dewasa Lebih Dini. 2) Belajar Menurut Kemauan Mereka Sendiri. 3) Semangat Untuk Menguasai.

Hal terpenting dari sebuah bakat adalah banyak anak yang tidak menyadari bakat yang mereka miliki, oleh karena itu guru dan orangtua yang harus jeli mengenali bakat yang dimiliki oleh anak. Jika anak sudah tertarik dengan bakat yang dimiliki, itu artinya ia juga berminat melakukan bakat tersebut. Disitulah anak akan berkembang sesuai dengan minat dan bakatnya.

\section{Teori Kecerdasan Ganda}

Teori kecerdasan ganda di populerkan oleh Prof. Howard Gardner, seorang ahli psikologi kognitif dari Universitas Hardvard, meneliti tentang kecerdasan manusia. Beliau menemukan bahwa setiap orang memiliki beberapa kecerdasan, tidak hanya satu kecerdasan. Kecerdasan adalah kemampuan untuk memecahkan masalah atau menciptakan suatu produk yang bernilai dalam satu latar belakang budaya tertentu (Lestari dkk, 2015:81).

Penelitian Gardner mengidentifikasi ada 8 macam kecerdasan manusia dalam memahami dunia nyata, kemudian diikuti oleh tokohtokoh lain dengan menambahkan dua kecerdasan lagi, sehingga menjadi 10 macam kecerdasan sebagai berikut :

a. Kecerdasan Bahasa (Linguistic Intelligence), yaitu kecerdasan bahasa mencakup kemampuan berpikir dengan kata-kata, seperti kemampuan untuk memahami dan merangkai kata dan kalimat baik lisan maupun tertulis. Komponen kecerdasan bahasa yang paling penting adalah kemampuan menggunakan bahasa untuk mencapai sasaran praktis.

b. Kecerdasan Logika/Matematik (Logical/Matematical

intelligence), yaitu kemampuan berpikir dalam penalaran atau menghitung, seperti kemampuan menelaah masalah secara logis, ilmiah dan matematis.

c. Kecerdasan Visual/Ruang (Visual/Spatial intelligence), yaitu kemampuan berpikir dalam citra dan gambar, seperti kemampuan membayangkan bentuk suatu objek.

d. Kecerdasan Musikal/Ritmik (Musical/Rhytmic Intellingence), yaitu kemampuan berpikir dengan nada, irama, dan melodi, juga pada suara alam.

e. Kecerdasan Kinestetik/Gerak Tubuh (Body/Kinesthetic 
Intelligence), yaitu kemampuan yang berhubungan dengan gerakan tubuh termasuk gerakan motorik otak yang mengendalikan tubuh seperti kemampuan untuk mengendalikan dan menggunakan tubuh dengan mudah dan cekatan.

f. Kecerdasan Intrapersonal (Intrapersonal Intelligence), yaitu kemampuan berpikir untuk memahami diri sendiri, melakukan refleksi diri dan bermetakognisi.

g. Kecerdasan Interpersonal (Interpersonal Intelligence), yaitu kemampuan berkomunikasi dan berinteraksi dengan orang lain.

h. Kecerdasan Naturalis (Naturalistic Intelligence), yaitu kemampuan untuk memahami gejala alam.

i. Kecerdasan Spritual (Spritualist Intelligence), yaitu kecerdasan yang berkaitan dengan bagaimana manusia berhubungan dengan Tuhan.

j. 10.Kecerdasan Eksistensial (Exsistensialist Intelligence), yaitu kemampuan menyadari dan menghayati dengan benar keberadaan dirinya di dunia ini dan apa tujuan hidupnya (Lestari dkk, 2015:82-86).

Pada dasarnya semua orang memiliki semua kecerdasan diatas, namun tentu saja tidak semuanya berkembang atau dikembangkan pada tingkatan yang sama, sehingga tidak dapat digunakan secara efektif.

\section{Anak Usia Dini}

a. Pengertian Anak Usia Dini

Anak adalah amanah terbesar dari Allah SWT sehingga kehadirannya begitu dinantikan oleh setiap manusia. Masa kanak-kanak merupakan masa emas dan momentum yang sangat berharga dan tidak dapat terulang kembali. Untuk itulah orangtua, guru, dan lingkungan sangat berperan dalam pembentukan jiwa dan karakter anak.

Menurut Masnipal (2013:78) pengertian anak usia dini ditujukan kepada anak yang berusia 0 - 6 tahun. Sedangkan anak usia dini menurut National Association fot The Education of Young Children (NAEYC) adalah anak yang berusia antara 0 sampai 8 tahun yang mendapatkan layanan pendidikan di taman penitipan anak, pendidikan pra sekolah baik negeri maupun swasta, taman kanak-kanak (TK) dan sekolah dasar (SD) (Aisyah, 2011:13).

b. Karakteristik Anak Usia Dini

Beberapa karakteristik anak usia dini menurut Hartati (2005:8) adalah sebagai berikut :

1) Memiliki rasa ingin tahu yang besar.

Anak usia dini sangat tertarik dengan dunia yang ada disekitarnya. Dia mencoba meraih benda-benda yang ada disekitarnya, memiliki keingintahuan yang besar terhadap lingkungannya, sehingga anak sering bertanya kepada orang dewasa, guru atau orangtuanya tentang hal-hal yang dianggap menarik oleh sang anak.

2) Merupakan pribadi yang unik.

Secara umum pola perkembangan anak usia dini adalah sama, namun perlu 
disadari bahwa tiap-tiap anak memiliki keunikannya masing-masing. Bahkan sekalipun anak tersebut kembar. Keunikan ini dapat berasal dari faktor genetik maupun berasal dari faktor lingkungan. Guru dan orangtua harus mengetahui hal ini, sehingga dapat memahami kebutuhan setiap anak.

3) Suka berfantasi dan berimajinasi.

Anak usia dini sangat suka berimajinasi dan berfantasi dengan pikirannya, kemudian anak dapat menceritakannya dengan begitu antusias, seolah-olah dia mengalaminya sendiri.

4) Masa potensial untuk belajar. Pada usia $0-8$ tahun perkembangan otak anak dapat mencapai $80 \%$, itulah mengapa pada usia ini disebut golden age yang merupakan masa paling potensial untuk anak dalam belajar guna mengoptimalkan tumbuh kembang.

5) Menunjukkan sikap egosentris.

Egosentris maksudnya anak usia dini pada umumnya hanya memahami sesuatu dari sudut pandangnya sendiri, bukan sudut pandang orang lain.

6) Memiliki rentang daya konsentrasi yang pendek.

Anak mudah teralihkan perhatiannya terhadap hal-hal yang lebih menarik, atau anak mudah bosan terhadap suatu hal yang dikerjakannya.

\section{METODE PELAKSANAAN}

Metode pelaksanaan pengabdian masyarakat ini menggunakan pendekatan kualitatif, data di peroleh dengan cara observasi, wawancara dan studi literatur. Kegiatan penyuluhan ini dilaksanakan pada hari Jumat, 24 Februari 2017 di TK Tunas Kejaksaan yang berlokasi di Kelurahan Cipayung, Kecamatan Ciputat, Tangerang Selatan.

\section{HASIL DAN PEMBAHASAN}

\section{Deskripsi TK Tunas Kejaksaan}

TK Tunas Kejaksaan berlokasi di Jalan Cipunegara 6 Blok C2 No. 4, Cipayung, Ciputat, Kota Tangerang Selatan, Banten 15411. Dipimpin oleh Ibu AAN Aryani, S.Pd selaku Kepala Sekolah TK Tunas Kejaksaan. Memiliki 5 orang guru dan 40 peserta didik. Bangunan sekolah berdiri diatas lahan $500 \mathrm{M}^{2}$, memiliki 1 ruang guru beserta kepala sekolah, 3 ruang kelas dan 1 sanitasi untuk peserta didik, taman dan lapangan.

\section{Cara Memetakan Potensi Unggul Anak Usia Dini}

Ada lima langkah konkret yang bisa dilakukan guru dan orangtua antara lain:

1. Langkah 1 : Menyusun Program Stimulasi.

Sukses dimulai dengan mengetahui bidang yang paling kita cintai. Jadi, langkah pertama adalah bantulah anak menemukan aktivitas apa saja yang disukainya. Jika seorang anak belum bisa mengungkapkan secara pasti dan meyakinkan tentang ingin jadi apa kelak jika ia sudah besar nanti, yang perlu kita lakukan adalah dengan memberikan sebanyak-banyaknya stimulasi. Stimulasi adalah memperkenalkan anak pada berbagai macam kegiatan dan profesi. 
Kenalkan anak pada semua profesi yang berhubungan dengan dunia industri, jasa, kerajinan, kesenian, serta berbagai macam pameran dan pentas seni. Ajaklah anak sesering mungkin melihat sebanyak-banyaknya aktivitas dan profesi yang ada di dunia ini. Contohnya bacakan buku mengenai aneka profesi kepada anak, temani anak menonton film, ajak anak mengunjungi pameran, museum dan pertunjukan, perkenalkan anak kepada aneka bidang olahraga dan tokoh-tokoh dunia.

Begitu banyak cara menyenangkan yang bisa dilakukan untuk menstimulasi anak. Dengan pengenalan ini, lambat laun minat anak akan mengerucut pada satu bidang profesi tertentu.

2. Langkah 2 : Membuat Daftar Minat dan Bakat.

Stimulasi terus tanpa henti sampai anak berusia 12 atau 13 tahun. Setelah stimulasi dalam waktu yang cukup, berarti anak sudah terpapar atau mendapat informasi mengenai sekian banyak ragam aktivitas atau profesi. Kini saatnya melakukan langkah kedua, yaitu membuat daftar minat dan bakat anak.

Caranya, buatlah daftar yang berisi aneka aktivitas atau bidang yang mereka minati minimal 10 aktivitas atau lebih banyak lebih baik, setelah itu beri skor pada masing-masing aktivitas sehingga akan ditemukan 3 aktivitas yang mendapatkan skor terbesar dan paling diminati anak. Kenapa 3? Karena biasanya minat seseorang bisa banyak dan beragam.

Setelah minat terbesar sudah ditemukan, langkah selanjutnya adalah trial atau uji bakat. Orangtua perlu menguji kemampuan anak dalam masing-masing bidang. Apakah kemampuannya memang mendukung minatnya? Apakah minatnya itu sekaligus juga adalah potensi unggulnya? Bila ia potensial pada semua minat terbesarnya, yang mana yang paling unggul?

3. Langkah 3 : Uji Coba Minat dan Bakat.

Uji coba minat dan bakat bisa dilakukan orangtua dengan memfasilitasi anak untuk menekuni minat-minat terbesarnya. Buka kesempatan lebih lebar bagi anak untuk mempelajari bidang-bidang ini. Uji bakat perlu dilakukan bukan hanya untuk melihat potensinya, tetapi juga melihat konsistensi anak. Konsistensi perlu kita perhitungkan agar tidak meleset dalam mengenali potensi unggul anak.

Idealnya uji bakat sebaiknya dilakukan selama 3 bulan sampai 1 tahun. Rata-rata setelah 3 bulan adalah periode yang membosankan bagi seorang anak untuk menekuni satu bidang bila bakatnya bukan disana. Setelah anak menjalani uji bakat, guru/pelatih dapat mengisi skor di kolom bakat dan orang tua dapat mengisi skor di kolom konsistensi.

Berdasarkan daftar minat, bakat dan konsistensi ada tiga hal yang perlu diperhatikan yaitu :

a. Apakah minat anak berasal dari dalam dirinya atau justru pengaruh dari luar?

b. Apakah anak berbakat dalam bidang yang diminatinya?

c. Apakah anak konsisten dalam menjalani bidang yang diminatinya? 
4. Langkah 4 : Penajaman Profesi.

Penajaman profesi adalah proses untuk menajamkan tujuan dari sebuah profesi. Penajaman profesi sangat penting karena penajaman ini akan menentukan spesialisasinya. Penajaman potensi bisa dilakukan dengan mengirim anak mempelajari bidangnya di sekolah terbaik. Ibarat mengasah pensil, kualitas pensilnya sudah bagus, kini kita tinggal mencari rautan terbaik untuk menajamkannya.

5. Langkah 5 : Make A Life Plan.

Life plan bagaikan peta yang akan membimbing anak untuk sampai ditujuannya. Misalnya tahun berapa anak ingin meraih citacitanya dan apa saja target pencapaiannya? Dengan begitu maka orangtua akan mengidentifikasi kebutuhan. Inilah yang disebut dengan "membalik" kebiasaan orangtua zaman sekarang. Jangan tentukan dulu sekolahnya sebelum ada tujuannya. Tetapi temukan dulu potensi unggul anak, tentukan tujuan spesifiknya, baru kita bisa mencari sekolah, jurusan, atau kursus apa yang akan mendukung anak meraih impiannya itu.

Ketika seorang anak memiliki life plan, hidupnya akan terfokus.
Jika anak fokus pada tujuan dan impiannya, serta fokus pada upaya meraih tujuan itu, ia akan jauh dari penyimpangan perilaku, penyalahgunaan narkoba, seks bebas, dan halhal yang mengerikan lainnya.

Jika life plan sudah dalam gengaman. Target pencapaian sudah ditetapkan. Selanjutnya, untuk memastikan perjalanan sukses anak berjalan baik, lakukanlah review berkala.

\section{Aplikasi Pemetaan Potensi Unggul Anak Usia Dini di Tunas Kejaksaan}

Berdasarkan wawancara dengan orangtua peserta didik ditemukan fakta bahwa hampir $90 \%$ orangtua belum menemukan bakat, minat dan potensi unggul anaknya. Hal ini disebabkan keterbatasan kemampuan, pengetahuan dan informasi terkait pemetaan potensi unggul. Setelah mendengarkan pemaparan Tim Abdimas Dosen Pendidikan Ekonomi terkait bagaimana cara memetakan potensi unggul, mereka baru mengetahui dan akan mencoba mengaplikasikannya ke anak masing-masing, karena mereka menyadari pentingnya pemetaan potensi unggul bagi kehidupan anak di masa depan.

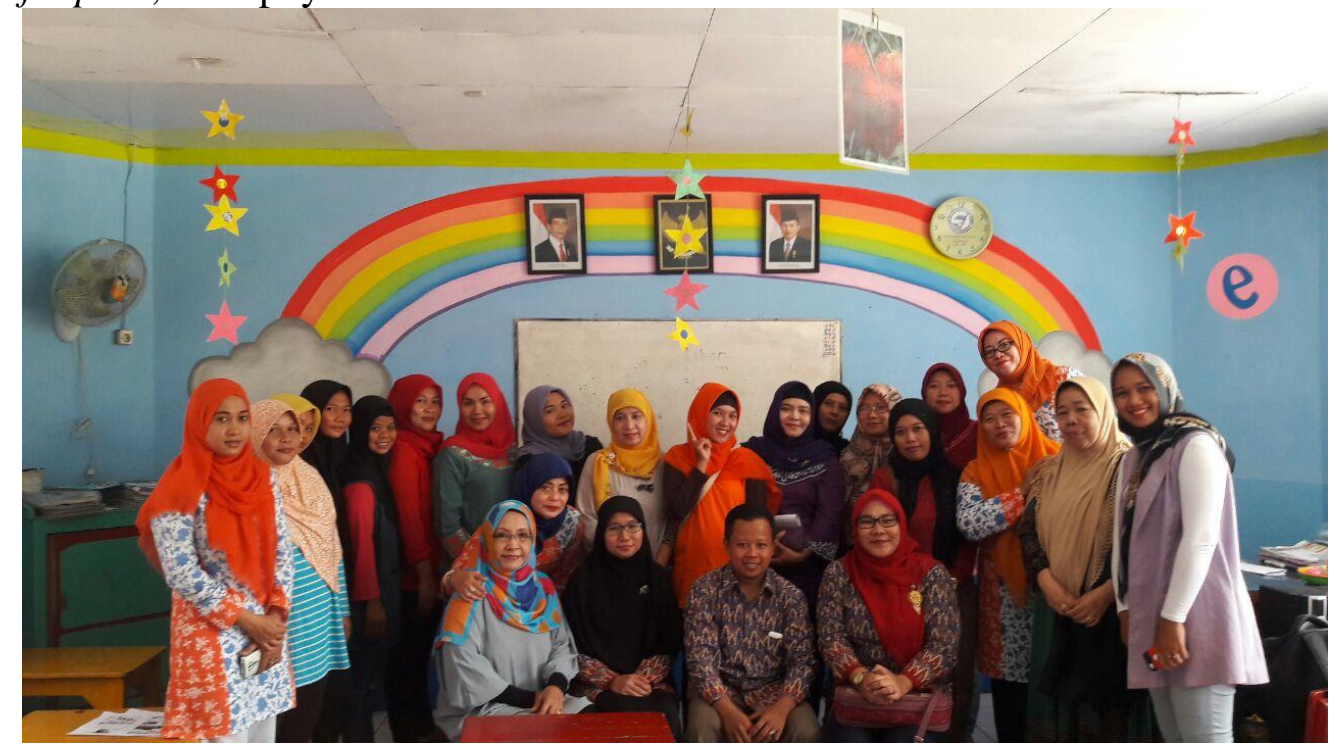




\section{SIMPULAN}

Berdasarkan hasil dan pembahasan dapat disimpulkan sebagai berikut:

1. Pemetaan potensi unggul dapat dilakukan melalui 5 langkah antara lain menyusun program stimulasi, membuat daftar minat dan bakat, uji coba minat dan bakat, penajaman profesi dan make a life plan.

2. Ditemukan fakta bahwa hampir $90 \%$ orangtua TK Tunas Kejaksaan belum menemukan bakat, minat dan potensi unggul anaknya.

Anak merupakan amanah terbesar yang Allah SWT titipkan kepada kita selaku orangtuanya, maka sudah seharusnyalah kita membimbing mereka menjadi anak yang soleh/soleha, cerdas, berakhlak dan bahagia. Kebahagiaan seorang anak dapat terwujud apabila orangtua dapat mengenali, menemukan, dan menggali potensi unggul anak sehingga mereka tumbuh sesuai dengan passion yang mereka miliki.

\section{DAFTAR PUSTAKA}

Aisyah, S. (2011). Perkembangan dan Konsep Dasar Pengembangan
Anak Usia Dini. Jakarta: Universitas Terbuka

Edi, A. (2014). Rahasia Ayah Edy Memetakan Potensi Unggul Anak. Jakarta:Noura Books.

Hartati, S. (2005). Perkembangan Belajar Pada Anak Usia Dini. Jakarta: Depdiknas.

Masnipal. (2013). Siap Menjadi guru dan Pengelola PAUD Profesional. Jakarta: Elex Media Komputindo.

Lestari, dkk. (2015). Strategi Belajar dan Pembelajaran. Jakarta: Unindra Press.

Santrock, J.W. (2008). Psikologi Pendidikan. Jakarta: Kencana Prenada Media Group.

Slameto. (2003). Belajar dan FaktorFaktor yang Mempengaruhinya. Jakarta: Rineka Cipta.

Surya, M. (2003). Psikologi Pembelajaran dan Pengajaran. Bandung: Remaja Rosda.

Syah, M. (1999). Psikologi Belajar. Bandung: Remaja Rosdakarya. 